have so far been produced, the latest being ' Church-Mission and State Relations in Preand Post-Independent Tanzania', by Lloyd W. Swantz. Six Occasional Bibliographies, on politics, government, anthropology, and sociology in Uganda, Kenya, and Tanzania have also appeared. A list of the papers, (price \$1.50 per copy, duplicated and bound in covers) may be obtained from Miss Joan Klein, East African Studies Program, I 9 College Place, Syracuse, New York.

\title{
Population Distribution Map of East Africa
}

Map Supplement Number Six of the Annals of the Association of American Geographers, 'East Africa-Population Distribution', was compiled in connexion with the Culture and Ecology in East Africa Project. The National Science Foundation and the National Institute of Mental Health provided financial support for this project, which was carried out by a team including Professor Philip W. Porter, the author of the map, and five anthropologists working under the direction of Dr. Walter Goldschmidt, Chairman of the Department of Anthropology, University of California, Los Angeles. The map, on a scale of $1: 2,000,000$, attempts to show the location of peoples in East Africa in a realistic and geographically correct manner, and to provide an administrative base map at the location/chiefdom level. Symbols are used to show location of settlements, and the reverse side of the map lists the name, number, and place within the administrative hierarchy of the statistical subdivision, as well as the area and population of each according to the most recent census and the calculated density for 1962 .

Copies of the map may be obtained from the Central Office, A.A.G., I 46 Sixteenth Street, N.W., Washington, D.C., 20036; price $\$ 2.90$ for the first copy, $\$ 2.00$ for each additional copy, post paid.

\section{Bibliography on Education in Africa}

Trevor Coоmen, Gail Gillam, and Sheldon Weeks are working on a partially annotated bibliography on education in African countries using English, to be published by the Harvard University Press, and would welcome correspondence from scholars working in this field. Replies should be addressed to Sheldon Weeks, Harvard University, 38 Kirkland Street, Cambridge, Massachusetts; or to Trevor Coombe, University of Zambia, Box 2379, Lusaka, Zambia.

\section{Commonvealth Film Award 1966}

THE Commonwealth Film Award for 1966 has been made to the Government of Swaziland Information Services for the film Lubalo (The Census), a colour film running for nine minutes, with a commentary in SiSwati, which was produced in the early part of 1966 to prepare the people of Swaziland for a forthcoming census of population, to show them how it would be conducted, and to emphasize its importance.

\section{The Haile Selassie Awards for 1966}

THE 1966 Haile Selassie Awards for African Research in 1966 have been given to Professor Roland Oliver, Professor of African History in the University of London, and Dr. H. C. Pereira, Director of the East Africa Agriculture and Forestry Research Organization. Professor Oliver's award is in recognition of his contribution to the development of African historical studies as 'a pioneer in the application of archaeological and anthropological evidence as well as in the use of collected oral tradition' and his encouragement and 